\title{
Yedinci Sınıf Fen Bilimleri Ders Kitaplarında Bilimin Doğası Temalarının İncelenmesi: Kuvvet ve Enerji Ünitesi
}

\section{Investigation of the Nature of Science Themes in Seventh Grade Science Textbooks: Force and Energy Unit}

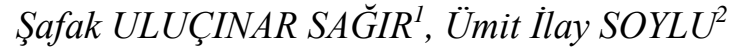

\begin{abstract}
${ }^{1}$ Sorumlu Yazar, Prof.Dr., Temel Ĕ̌itim Bölümü, Eğitim Fakültesi, Amasya Üniversitesi, Türkiye,safak.ulucinar@amasya.edu.tr, (https://orcid.org/0000-0003-3383-5330)

2 Doktora ögrencisi, Fen Bilimleri Ĕ̆itimi Anabilim Dall, Fen Bilimleri Enstitüsü, AmasyaÜniversitesi, Türkiye, ilaysoylu@ gmail.com, (https://orcid.org/0000-0002-01870986)
\end{abstract}

Geliş Tarihi: 14.04.2021

Kabul Tarihi: 26.11.2021

\section{ÖZ}

Ders kitapları öğretimde önemli ve sık kullanılan bir materyaldir. Bu araştırmada, ders kitabı olarak 20192020 eğitim öğretim yılında okutulan ve EBA'da verilen "Ortaokul ve İmam Hatip Ortaokulu 7. Sinıf Fen Bilimleri Ders Kitabı" başlıklı MEB Yayınları (1. Kitap) ve özel bir yayınevinden (2. Kitap) çıkan iki kitap yer almaktadır. 7. sınıf fen bilimleri kitaplarında yer alan Kuvvet ve Enerji ünitesinin bilimin doğasıla ilgili temaları içermesi bakımından incelenmesi amaçlanmıştır. Analitik araştırma yöntemlerinden doküman analizi yöntemi kullanılmıştır. Araştırmada Niaz ve Maza (2011) tarafından verilen dokuz bilimin doğası temasına göre hazırlanan rubrik ile veriler toplanmıştır. İncelenen kitaplarda Kuvvet ve Enerji ünitesinde bilimin doğası temalarının yeterli düzeyde temsil edilmedikleri belirlenmiştir. En fazla değinilen tema "gözlemlerin teori yüklü" olduğu ve "bilimsel bilginin deney, gözlem ve akıl yürütmeye dayalı" olduğu temalarıdır. Bilimde teorilerin yeri, bilimsel yöntem, yasa ve teorilerin farkı temalarına iki kitapta da hiç değinilmediği tespit edilmiştir. İncelenen iki kitabın bilimin doğasını öğretimini dolaylı olarak desteklediği sonucuna varılmıştır. Fen bilimleri ders kitaplarının diğer ünitelerinin de bilimin doğası temalarını kapsaması bakımından incelenmesi ve fen ders kitabı yazımında bu temalara daha fazla vurgu yapılması önerilmiştir.

Anahtar Kelimeler: Fen Eğitimi, bilimin doğası, fen bilimleri ders kitabı.

\begin{abstract}
Textbooks are an important and frequently used material in teaching. In this research, which was taught as a textbook in the 2019-2020 academic year and given in EBA "Middle School and Imam Hatip Middle School 7. Class Science Textbook" titled MEB Publications (1. Book) and a private publisher (2. Book) are included in the two books. The Force and Energy unit in the 7th grade science books is intended to be examined in terms of containing themes related to the nature of science. Document analysis method, one of the Analytical Research methods, was applied in the research. In the research, the data were collected with the rubric prepared by taking into account the nine nature of science theme given by Niaz and Maza (2011). It was determined that the nature of science themes in the Force and Energy unit were not sufficiently represented in the reviewed books. The most emphasized themes are that "observations are theory-laden" and "scientific knowledge is based on experimental, observation and reasoning". It has been determined that the place of theories in science, scientific method, and the difference of laws and theories are not mentioned in either of the books. It was concluded that the two books examined indirectly support
\end{abstract}


teaching the nature of science. It was suggested that more emphasis should be placed on these themes in science textbook writing since other titles of science textbooks also cover the nature of science themes.

Keywords: Nature of science, science education, science textbook.

\section{GíRiş}

Modern toplumlar bilim ve teknolojide ilerleyebilmek için fen eğitiminin niteliğini arttırmaya gayret göstermektedirler (Aydede, 2006). Bu nedenle fen öğretim programlarının sürekli yenilenmesi söz konusudur (Milli Eğitim Bakanlığı [MEB], 2005). Ülkemizde fen bilimleri dersi öğretim programı yapılandırmacı öğrenme yaklaşımını esas alarak 2005 yılında değiştirilmiş, sonrasında araştırma sorgulamaya dayalı öğrenme yaklaşımı temel felsefesiyle 2013 sonrasında 2017 ve 2018 yıllarında yeniden düzenlenmiştir (MEB, 2005, 2013, 2017, 2018). Belirtilen programlarda fen okuryazarlığı kazandırmak amaçlanmıştır. Birçok ülkede de fen eğitiminde fen okuryazarlığına vurgu yapılmış (American Association for the Advancement of Science [AAAS], 1993; National Research Council [NRC], 1996; National Science Teachers Association [NSTA], 2013); araştırma sorgulama temelli öğrenme, proje tabanlı öğretim, argumantasyon gibi yaklaşımlarla ve yöntemlerle bilimsel okuryazarlığının geliştirilmesi hedeflenmiştir.

Bireylerin bilgideki hızlı devinime adapte olabilmeleri ve karşılaştıkları yeni durumlar sonucu oluşan problemlere çözüm üretebilmeleri için eğitim süreçlerini bilim okuryazar bireyler olarak tamamamaları gerekir. Bilimsel okuryazarlık genel olarak; "bilimsel kavramları, ilkeleri, teorileri bilmek; bilimsel süreci anlamak; bilim, teknoloji ve toplum arasındaki ilişkinin bilincinde olmak" şeklinde tanımlanmıştırr (Abd-El-Khalick, Bell ve Lederman, 1998). Bilimsel okuryazar bireyler fenle ilgili temel kavram bilgisine sahip, bilimin teknolojiye etkisini anlayan, bilimin doğasını anlayan, yaşadıkları dünyadaki sorunları algılayıp çözüm önerilerinde bulunan, karar verme süreçlerine katılan ve bu süreçte bilimsel bilgisinden faydalanabilen bilinçli bireylerdir (AAAS, 1993; Harlen, 2001; Köseoğlu ve diğerleri, 2003). Bilimsel okuryazarlığının kavramsal çatısına; bilimin doğasını ve kültürle ilişkisini anlama, bilimi ve uygulamalarını anlama; bilimsel düşünebilme becerisine sahip olma gibi kavramlar dahil edilmiştir (Norris ve Philips, 2003). Bilimsel okuryazarlığın önemli bir bileşenini bilimin doğası oluşturmakta ve bilimsel okuryazarlığın bilimin doğasına dayanan bir fen eğitimi ile kazandırılacağı belirtilmektedir (AAAS, 1993; McComas ve Olson, 1998). Bu nedenle öğretim programlarında bilimin doğasına yer verilmektedir. Fen bilimleri dersi 2013 öğretim programında "Fen-Teknoloji-Toplum-Çevre öğrenme alanında" bilimin doğasına yer verilmiş özel amaçlarda bilimin doğası bilim teknoloji ilişkisi ve bilim toplum ilişkisi belirtilmiştir. 2018 fen bilimleri öğretim programının özel amaçlarında;

- 2. Doğanın keşfedilmesi ve insan-çevre arasındaki ilişkinin anlaşılması sürecinde, bilimsel süreç becerileri ve bilimsel araştırma yaklaşımını benimseyip bu alanlarda karşılaşılan sorunlara çözüm üretmek

- 6. Bilim insanlarınca bilimsel bilginin nasıl oluşturulduğunu, oluşturulan bu bilginin geçtiği süreçleri ve yeni araştırmalarda nasıl kullanıldığını anlamaya yardımcı olmak

olarak bilimin doğasıyla ilgili özelliklere değinilmiştir (MEB, 2018, s. 9).

Lederman (1992)'a göre bilimin doğasını anlamak bilimsel okuryazarlık için gerekli bir durumdur. Bilim okuryazarı bireylerin yetiştirilmesi için en önemli bileşenlerden biriside bilimsel sorgulamadir (Next Generation Science Education Standarts [NGSS], 2013). Lederman, Lederman, Bartels, Jimenez ve diğerlerine (2019) göre, bilimsel okuryazarlığın yeterli düzeyde olabilmesi için öğrencilerin bilimsel sorgulama becerileri ile ilgili doğru bilgiye sahip olmalarıyla doğrudan ilişkisi vardır. Ortaokul kademesinde okuyan öğrencilerin bilimsel okuryazarlığ yeterlilik ve bilgilerini geliştirdiği için gelecek eğitim sürecini şekillendirme noktasında en 
önemli kademelerdendir (MEB, 2015). Doğan, Han Tosunoğlu, Özer ve Akkan (2019) yaptıkları çalışmada, bilimsel sorgulamanın tüm bileșenleriyle ilgili ortaokul öğrencilerinin görüşlerinin yetersiz olduğunu belirtmişlerdir. Muşlu (2008) çalışmasında, bilimin doğası ve çağdaş bilim anlayışı çerçevesinde bazı alanlarda yeterli görüşe sahip olmadıklarını ifade etmişlerdir. Bilimin doğasını McComas, Clough ve Almazroa (1998); "bilimin doğası, tarih, sosyoloji ve felsefe gibi sosyal alanlarla psikoloji gibi bilişsel alanları, bilim nedir, nasıl çalışır, bilim insanları sosyal bir grup olarak nasıl çalışırlar ve toplum bilimsel girişimleri nasıl yönlendirir sorularının zengin tanımlarını içinde birleştiren yaratıcı ve verimli bir alandır" (s. 4) olarak tanımlamaktadır. Taşar'a (2003) göre bilimin doğası, "bilimin nasıl yapıldığını, bilimin ne olduğu ve hangi rolleri içerdiğini, bilim insanlarının kim olduğu ve hangi rolleri üstlendiklerini, bilimsel ipuçlarını, gözlemleri, olayları, kuralları, kanunları ve bilimsel metodu kavramayı içeriğinde barındırır" (s. 31) şeklinde belirtilmiştir. Lederman (2007) bilimsel bilginin ve bilimin özelliklerine vurguladığ1 için bilimin doğasına ilişkin tanımlamaların hepsini geçerli bulmaktadır.

Genel olarak bilimin doğasıyla ilgili özellikler değişebilir yap1, deneysellik, bilimsel yöntem, yaratıcılık, hayal gücünün yeri ve öznellik, teori ve kanun farkı, gözlem ve çıkarım fark1, sosyal ve kültürel yapının etkisi temaları belirtilmektedir (Bell, Abd-El-Khalick, Lederman, McComas, ve Matthews, 2001; Doğan Bora, 2005). Literatürdeki araştırmalar öğretmen, öğretmen adayları ve farklı düzeydeki öğrencilerin bilimin doğasına yönelik anlayışlarının yetersizliğini belirtmektedir (Abd-El-Khalick ve Akerson, 2004; Aslan, Yalçın ve Taşar, 2009; Bianchini ve Colburn, 2000; Lederman, 1992; Muğaloğlu, 2006; Niaz, 2009; Oyman, 2002). Bu durumun ortaya çıkmasında en önemli iki sebepten bahsedilebilir. Birincisi öğretmenlerin yetiştirilme süreciyle, ikincisi konuların öğretim programında ve ders kitaplarında ele alınış şekliyle ilgilidir (Abd-El-Khalick, Waters ve Le, 2008). Ders kitapları fen eğitimi için önemlidir (Chiappetta, Sethna ve Fillman, 1993) ve öğretmenlerinin bilimin doğası hakkındaki inanışları öğrencilerin bilimin doğası algılarını etkilemektedir (Doğan Bora, 2005).

Öğretim programının uygulanmasında ders kitapları, özellikle alanı dışında bir konuda öğretim yapıyorsa öğretmenlerin güvendiği önemli kaynaklardır (Stern ve Roseman, 2004). Birçok fen bilgisi öğretmeni temel kaynak olarak fen kitaplarını kullanmaktadır. Kötü hazırlanmış müfredat materyalleri, hem öğrencilerin hem de öğretmenlerin etkili öğretim uygulamalarını anlamalarına engel olabilir (Abraham, Grzybowski, Renner ve Marek, 1992). Fen ders kitapları bilgileri düzenleme, sorgulamaya rehberlik etme, bilimsel gerçekleri sunma, problem çözme becerilerini geliştirme, somutlaştırma, okuma becerilerini geliştirme, öğrenmeyi pekiştirme ve örneklendirmeye yardımcı olduğu araştırma raporlarında verilmektedir (Chiappetta, Ganesh, Lee ve Phillips, 2006). Literatürde ders kitaplarının düşük bilişsel düzeyde sorgulamayı vurguladığı (Overman, Vermunt, Meijer, Bulte, ve Brekelmans, 2013), öğrenci ön bilgilerini dikkate almadığ (Stern ve Roseman, 2004), bilimsel yanlışlar ve genellemeler içerdiği (Hubisz, 2003), bilimteknoloji-toplum konularını ele alırken sınırlı kaldığı, sosyobilimsel konuları işlerken çok disiplinli bağlantının kurulamadığı (Chiang-Soong ve Yager, 1993) gibi durumlar belirtilmektedir. Kitaplardaki çizimler, örnekler ve etkinlikler yoluyla öğrencilerin bilimle ilgili düşünceleri değişmekte, yanlış yönlendirilmektedir (Akerson, Buzzelli ve Donnelly, 2008).

Farklı ülkelerde bilimin doğasının ders kitaplarında temsil düzeyi son yıllarda oldukça popüler bir konudur. Vesterinen, Aksela ve Lavonen (2013), İsveç ve Finlandiya kimya kitaplarında bir bütün üzerinde düşünmenin yolu olarak bilime ve bilimin doğasının geçicilik boyutuna az vurgu yapıldığını belirtmişler, müfredatlarda düzenlemelerle ders kitaplarında bilimin doğasının geliştirilmesi yönünde öneride bulunmuşlardır. Bazı çalışmalar örneğin, Abdel-Khalick ve diğerleri (2008), Aydın ve Tortumlu (2015), İrez (2009), Niaz ve Maza (2011), Şahin ve Köseoğlu (2016) kimya, biyoloji ve fen bilimleri ders kitaplarında bilimin doğası temalarının bazılarının olmadığ veya yetersiz ve dengesiz bir şekilde temsil edildiğini belirtmektedirler. Öğrencinin, bilimin doğasının özünü kavrayabilmesi ve anlayabilmesi için okullarda verilen fen eğitiminde bilimin doğası önemli yer tutmaktadır. Öğretmenlere bu süreci yönetme ve kitap materyalinden yararlanma noktasında büyük görev düşmektedir. Bu bağlamda 
revize edilen 2018 Fen Bilimleri Dersi Öğretim Programı'na göre hazırlanan ders kitaplarının incelenmesi gerekli görülmüştür. Yapılan çalışmalarda daha çok kimya konularına rastlanmış olup Kuvvet ve Enerji konusuna rastlanılmadığından bu konu seçilmiştir. Bu araştırmanın amacı 2018 Fen bilimleri öğretim programındaki güncellemelerden sonra hazırlanan 7. sınıf Fen Bilimleri Ders Kitabından Kuvvet ve Enerji ünitesinin bilimin doğası temaları bakımından incelenmesidir.

\section{YÖNTEM}

\subsection{Araştırmanın Modeli}

$\mathrm{Bu}$ çalışmada doküman analizi yöntemi kullanılmıştır. Nitel çalışmalarda, araştırma konusuyla ilgili elde edilen materyallerin incelenmesini sağladığ analizidir (Cansız Aktaş, 2019). Çepni (2014) bu yöntemi," araştırılması yapılacak konu ile ilgili belgeleri toplayıp belirli bir sisteme göre kodlayarak inceleme işlemi" olarak tanımlamıştır. Yıldırım ve Şimsek (2013) doküman incelemesini "araştırılması hedeflenen olgu veya olgular hakkında bilgi içeren yazılı materyallerin analizini kapsar" şeklinde açıklar. Çalışmada 7. sınıf fen bilimleri ders kitaplarına Millî Eğitim Bakanlığı (MEB)'nın internet adresinden ulaşılarak, ders kitabında yer alan Kuvvet ve Enerji üniteleri incelenmiştir.

\section{2. Örneklem}

Çalışmanın evrenini 7. sınıf fen bilimleri ders kitapları oluşturmaktadır. Çalışmanın örnekleminde ise MEB, "Talim ve Terbiye Kurulunun 18.04.2019 gün ve 8 sayılı kararı ile 5 yıl süreyle ders kitabı olarak kabul edilmiş, Ortaokul ve İmam Hatip Ortaokulu 7. Sınıf Fen Bilimleri Ders Kitabı" başlıklı MEB Yayınları'ndan (Akdemir ve Çetin Atasoy, 2019; 1. Kitap) ve "Ortaokul ve İmam Hatip Ortaokulu 7. Sınıf Fen Bilimleri Ders Kitabı" başlıklı özel bir yayınevinden (Seyrek ve diğerleri, 2019; 2. Kitap) basılan iki kitap yer almaktadır. İncelenecek kitapların seçiminde şu an okullarda okutulan, 2019 yılında yayınlanan, yeni müfredata göre düzenlenmiş, araştırma esnasında MEB Eğitim Bilişim Ağı'nda (EBA) yer alan, internet adresi üzerinden erişimi açık olan kitaplar olmasına dikkat edilmiştir. Bir ders kitabındaki tüm ünitelerde öğretim programlarının amaçlarının gerçekleştirilmesi hedeflendiğinden konu seçiminde bir kriter aranmadan rastgele seçimle Kuvvet ve Enerji ünitesi ele alınmıştır. İncelenen kitaplardan 1. kitap 246 sayfa, incelenen bölüm 27 sayfa; 2. kitap 256 sayfa, incelenen bölüm 33 sayfadır. 1. kitapta içerik analizi yapılan bölüm tüm kitabın \%11,'ini, 2. kitapta \%13'ünü oluşturmaktadır.

\subsection{Veri Toplama Aracı}

Ders kitabında ünitenin incelenmesinde Niaz ve Maza (2011) tarafindan verilen bilimin doğası temalarını içeren rubrik ile veri toplanmıştır. Bu temalar aşağıda listelenmiştir.

“1) Bilimsel teorilerin geçici/kesin olmayan doğast vardır.

2) Bilimde yasa ve teorilerin farklı rolleri vardır (Teoriler ilave kanitlarla birlikte yasalara dönüşmez.)

3) Evrensel ve aşama aşama ilerleyen bir bilimsel yöntem yoktur.

4) Gözlemler teori yüklüdür.

5) Bilimsel bilgi tamamen olmasa da çoğunlukla gözleme, deneysel kanıta, rasyonel argümanlara, yaratıcılı̆̆a ve şüpheciliğe dayalıdır.

6) Bilimsel ilerleme, rakip teoriler arasindaki rekabet ile nitelendirilir.

7) Bilim insanları, aynı deneysel veriyi farklı biçimlerde yorumlayabilir.

8) Bilimsel teorilerin gelişimi bazen çelişen temellere dayalıdır.

9) Bilimsel fikirler, oluşturulduğu sosyal ve tarihsel ortamdan etkilenir."

Analiz sırasında temalar T1-T2-T3-T4-T5-T6-T7-T8 ve T9 şeklinde kodlarla belirtilmiştir. 


\subsection{Verilerin Analizi}

Bu çalışmada betimsel içerik analizi yapılmıştır. Betimsel içerik analizi yazılı, basılı, görsel belgeler içinde bulunan bilgilerin belirlenen kodlara göre arandığı, daha yüzeysel bir analizdir (Y1ldırım ve Şimsek, 2013).

Niaz ve Maza (2011), 75 kimya kitabının girişlerini inceledikleri kitapta üç değerlendirme düzeyi tanımlamaktadır. İlki tatmin edici düzey; kriterin tanımlandığ 1 ve örneklerle açıklandığ durumdur. İkincisi, bahsedilmiş/değinilmiş düzey; çok az ayrıntı olan ve hiç örnek verilmediği durum ve son olarak hiç bahsedilmemiş/değinilmemiş düzey; ölçütle ilgili konulardan hiç bahsedilmediği durumdur. Bu çalışmada, 7. sınıf fen bilimleri kitabı Kuvvet ve Enerji ünitesinde bilimin doğasını oluşturan temaları karşılama düzeyleri yeterince değinilmiş (Y), değinilmiş (D) ve eksik/yetersiz (E) olarak derecelendirilme yapılmıştır. Hazırlanan rubrikte incelenen ünitede ilgili tema hiç bulunmuyorsa 0 puan, orta düzeyde bulunuyorsa/değinilmişse 1 puan, yeteri kadar bulunuyorsa 2 puan olarak puanlanmıştır. Güvenirliğin kontrolü için Miles ve Huberman'ın (1994) önerdiği güvenirlik formülü kullanılmıştır. Bir temel eğitim uzmanı ve bir doktora öğrencisi toplamda iki araştırmacı puanlama yapmıştır. Miles Huberman formülüyle [Güvenirlik $=$ Görüş Birliği/(Görüş Birliği + Görüş Ayrıllğı)] güvenirlik 0,87 olarak bulunmuştur. Miles ve Huberman'a (1994) göre iç tutarlı̆̆ 1 veren kodlayıc1lar aras1 görüş birliğinin \%80'in üzerinde çıkması gerekmektedir.

\section{BULGULAR}

7. sınıf fen bilimleri dersi kitaplarında Kuvvet ve Enerji ünitesindeki kazanımların bilimin doğası temalarının frekansları incelenmiştir. "Ortaokul ve İmam Hatip Ortaokulu 7. Sınıf Fen Bilimleri Ders Kitabı" başlıklı MEB Yayını olan kitap (1. Kitap) 1.K ve özel bir yayınevinden olan kitap (2. Kitap) 2.K olarak kodlanmıştır. Bundan sonraki resimlerin altındaki kaynak gösterimlerde $1 . \mathrm{K}$ ve $2 . \mathrm{K}$ olarak belirtilecektir. Tablo 1'de incelenen kitaplarda belirlenen bilimin doğası temalarının frekansları ve temsil düzeyleri verilmiştir. 
Tablo 1. Fen Bilimleri Kitaplarında Kuvvet ve Enerji Ünitesinde Bilimin Doğası Temalarının Frekansları ve Temsil Düzeyleri

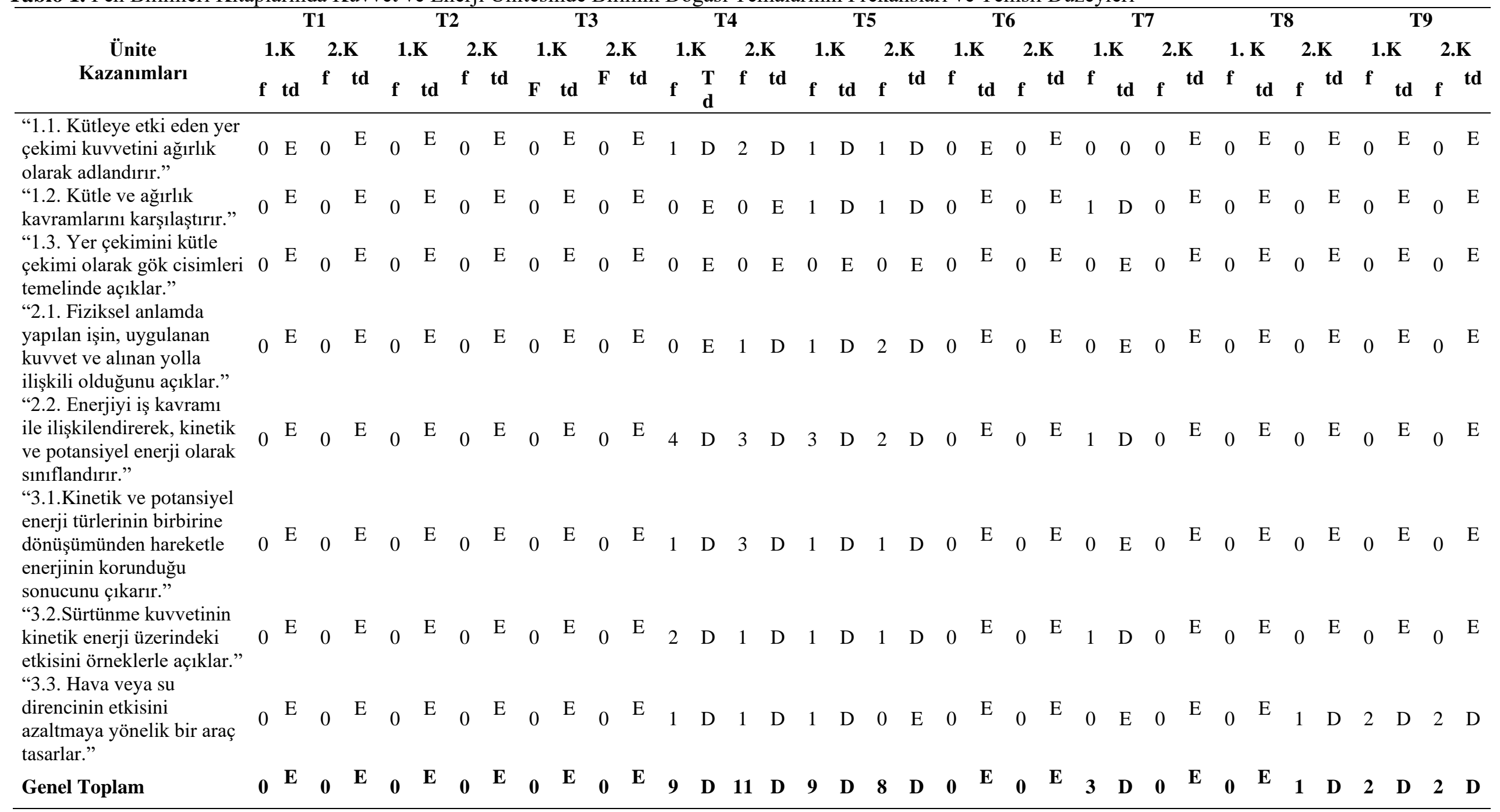

f:sıklık td: temsil düzeyi 1. K: Akdemir ve Çetinsoy (2019) 2.K: Seyrek vd. (2019) 
Tablo 1'de MEB yayını olan 1.K'nın ve özel yayınevine ait 2.K'nın Kuvvet ve Enerji ünitesindeki bilimin doğası temalarını içermelerine göre en fazla frekansın 4. "Gözlemler teori yüklüdür." ( $\mathrm{f}=9-11)$ ve 5. "Bilimsel bilgi tamamen olmasa da çoğunlukla gözleme, deneysel kanıta, rasyonel argümanlara, yaratıcılığa ve şüpheciliğe dayalıdır." (f=9-8) temalarında olduğu görülmektedir. İlk 3 tema için iki kitapta da dolaylı veya doğrudan bir gösterim bulunamamıştır. Tablo 2'de incelenen kitapların bilimin doğası temalarına göre puanlaması yapılmıştır.

Tablo 2. İncelenen Kitapların Bilimin Doğası Temalarına Göre Değerlendirilmesi

\begin{tabular}{llcc}
\hline & Temalar & 1. Kitap & 2. Kitap \\
\hline T1 & Bilimsel teorilerin geçici/kesin olmayan doğası vardır. & 0 & 0 \\
T2 & Bilimde yasa ve teorilerin farklı rolleri vardır. & 0 & 0 \\
T3 & Evrensel ve aşama aşama ilerleyen bir bilimsel yöntem yoktur. & 0 & 0 \\
T4 & Gözlemler teori yüklüdür. & 2 & 2 \\
T5 & Bilimsel bilgi tamamen olmasa da çoğunlukla gözleme, deneysel kanıta, & 2 & 2 \\
& rasyonel argümanlara, yaratıcıllı̆̆ ve şüpheciliğe dayalıdır. & 0 & 0 \\
T6 & Bilimsel ilerleme, rakip teoriler arasındaki rekabet ile nitelendirilir. & 1 & 0 \\
T7 & Bilim insanları, aynı deneysel veriyi farklı biçimlerde yorumlayabilir & 0 & 1 \\
T8 & Bilimsel teorilerin gelişimi bazen çelişen temellere dayalıdır. & 1 & 1 \\
T9 & Bilimsel fikirler, oluşturulduğu sosyal ve tarihsel ortamdan etkilenir. & 1 \\
\hline
\end{tabular}

Kuvvet ve Enerji ünitesi 8 kazanım içermektedir. Bu kazanımları dikkate alarak belirlenen bilimin doğası temalarının incelenmesinde en fazla T4 ve T5 temasına değinildiği tespit edilmiştir. Kazanım başına frekans düşünülerek 2 puan verilmiştir. Her iki kitapta da verilen etkinlikler ve açıklamalarda bilimsel bilginin deney, gözlem, akıl yürütmeye dayalı olduğu, gözlemlerin teori yüklü olduğuna daha çok değinilmiştir. Bilimsel fikirlerin oluşturulduğu ortamdan etkilenmesi (T9) iki kitap da 1 puan almıştır. 1. kitap 7. temada ve 2. Kitap 8. temada temsil frekansı düşük olduğundan 1 olarak puanlanmıştır. Bundan sonraki başlıklarda her iki kitapta temaların temsil durumları örneklerle verilecektir.

\section{Kitapta Bilimin Doğası Temalarının Temsili}

4. tema olan "gözlemler teori yüklüdür" teması, $1 . K^{\prime}$ da en fazla sayıda temsil edilen temalardandır. 96. sayfa bu temaya bir örnek verilebilir. 96. sayfaya yönelik metin Şekil 1'de verilmiştir. 
Ellerinizi birbirine hızlı bir şekilde görseldeki gibi sürtünüz. Ellerinizdeki sıcaklık artışının nedeni ne olabilir?

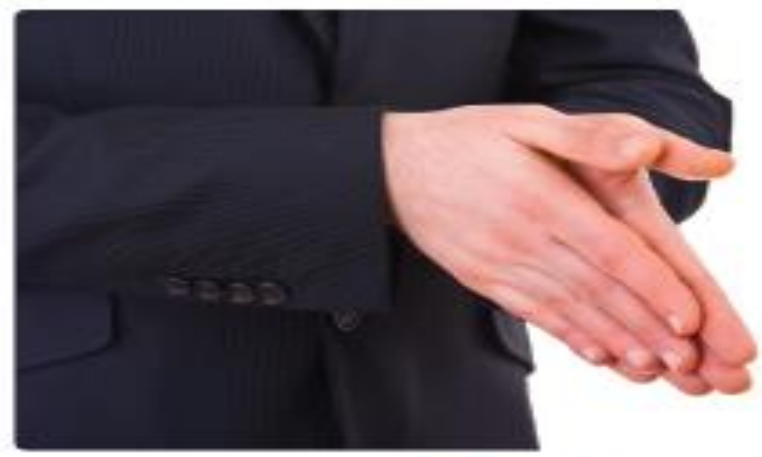

EWerin Durbirine sarten kłş

Bir madde ya da yüzeyle temas hallinde olan hareketli bir cismin hareketine devam etmesi için o cisme sürekli kuvvet uygulanması gerekir. Aksi hâlde hareketini devam ettiremez.

Kuwvet uygulanan top belli bir süre ilerledikten sonra yavașlar ve durur. Așaḡıdaki görsellerde eşit kuvvetle itilen özdes toplardan hangi zemindekinin daha süratli ilerleyeceḡini dưșününüz. Düşüncelerinizi arkadaşlarınızla tartıșınız.

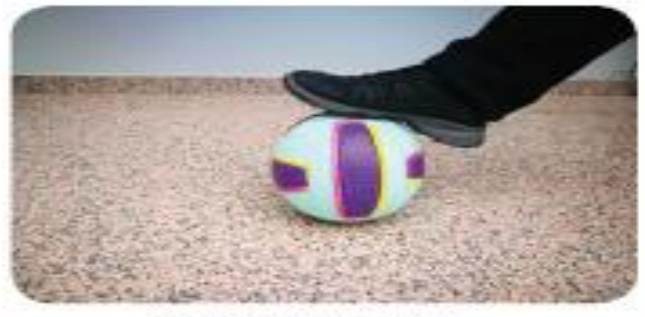

Betan zemin (az poruzto)

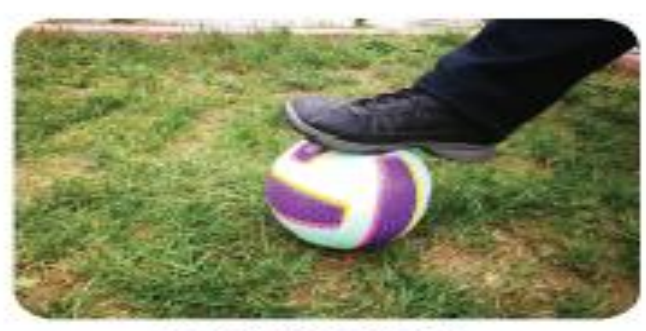

Çim zernin (çok poruzwo)

Şekil 1. "Gözlemler Teori Yüklüdür” Temasına Örnek (1K, s. 96)

Şekil 1, sayfa 96'da verilen etkinlikte öğrencilerin ellerini birbirine sürtmesini, gözlem yapmasını ve gözlem sonucunu açıklaması istenmektedir. Şekil 1'de verilen iki görselde de gözlem yapmalarını ve çıkarımda bulunmaları istenmiştir. Her öğrencinin gözlem sonuçlarına ilişkin yorumu özneldir ve bu anlamda teori yüklüdür. Öğrenciler gözlemlerini yorumlarken önceki deneyimlerinden, bildiklerinden ve akıl yürütmeden yararlanacaklardır. Verilen örnekler aynı zamanda "Bilimsel bilgi tamamen olmasa da çoğunlukla gözleme, deneysel kanıta, rasyonel argümanlara, yaratıcılığa ve şüpheciliğe dayalıdır." temasını da karşılamaktadır. 80, 90, 91, 92, 93, 94 ve 99. sayfalarda da gözlemlerin teori yüklü olduğu çıkarımı yapılmıştır.

Birinci kitapta 5. tema olan "bilimsel bilgi tamamen olmasa da çoğunlukla gözleme, deneysel kanıta, rasyonel argümanlara, yaratıcılığa ve şüpheciliğe dayalıdır" temasına 82., 85., 90., 91. ve 98. sayfalarda da vurgular yapılmıştır. Sayfa 98'e yönelik metin Şekil 2'de verilmiştir. 
* 1 adet $1,5 \mathrm{~m}$ uzunlugunda urgan ip

- Içift eldiven

- 1,5 m urunlugunda ahsap sopa (soporge sape vb. kullanilabilir.)

- Bu etkanilikteka amac, sartunme kurvetinin kinetik enerji uzerindeki etkasint kavramaktar.

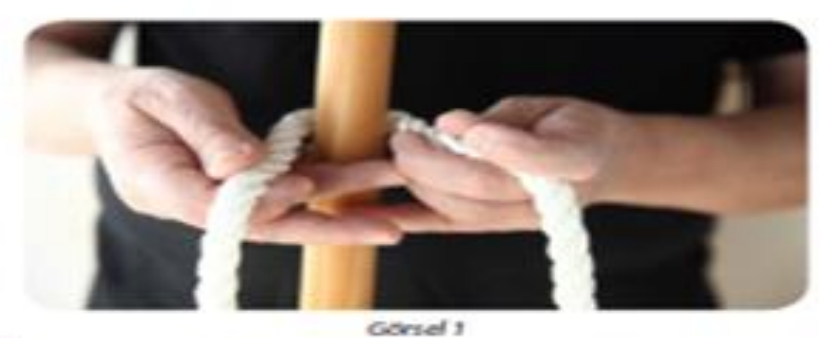

Etkiniligin rapeling:

Cossed $:$

1- Ipin ve ahgap sopanin sucaklıgini elinizle kontrol edintz.

2-Ipl ahsap sopaya dolamadan sekaldeki gibi bir kez sopanin etrafindan geciriniz.

3- Eldwenlerintza glytiniz ve arkadasanizdan ahsap sopanin ika ucunu sakaca tutmasana Istegintz.

4- Iptn bir ucunu bir elintzle, diger ucunu oteki elintzle sakaca tutunuz. A rkadaşanizdan uraklasarak ipin gergin olmasini saglayincz.

5- Ipi bir sag elintzle bir de sol elinizle ardisık olarak surekil çekerek sopaya surtunaz. Ipt sopanin hep aymi bolgesine sartanoz.

6- Sopanin donmediginden emin bir sekaldie bu hareketi 3 dakika kadar devam etturintz.

7-sore dolduktan somra eldivenlerinizi çkartarak ipln ve ahsap sopada sortanmenin oldugu bolgenin sicaklingini kontrol edintz.

a Ahsap sopa ve iptin sacakliginda nasal bir degisaklik megdana geldir?

Os sicakliktaki degtsimin nedent ne olabilir?

(a) Etkanikkte bir enerj donaşomo meydana geldi mir Geldtyse bu donosum hangt tor enerjler arasunda gerceklestu?

Şekil 2. "Bilimsel Bilgi Tamamen Olmasa Da Çoğunlukla Gözleme, Deneysel Kanıta, Rasyonel Argümanlara, Yaratıcılığa ve Şüpheciliğe Dayalıdır” Temasına Örnek (1.K, s.98)

Şekil 2, sayfa 98'de yer alan etkinlikte öğrencilerin yapılacak olan deneyde bilimsel bilgiye ulaşma sürecinin farklı etmenleri sağlanmıştır. Deney ve gözlem yaptırılarak sonuçları üzerinde düşünmeleri istenmiştir. Bilim insanlarının da bilgiye ulaşırken deney, gözlem, akıl yürütme ve şüpheciliğe dayanan işlemler yaptığını düşünmeleri dolaylı olarak hedeflenmiştir.

7. tema olan "bilim insanları, aynı deneysel veriyi farklı biçimlerde yorumlayabilir" temasına 7. sınıf fen bilimleri 1.K ders kitabında 82. sayfasında vurgu yapılmıştır. Bu çıkarıma yönelik etkinlik Şekil 3'te verilmiştir. Benzer şekilde ders kitabının 82., 91. ve 98. sayfalarında da bu temaya vurgular yapılmıştır. 


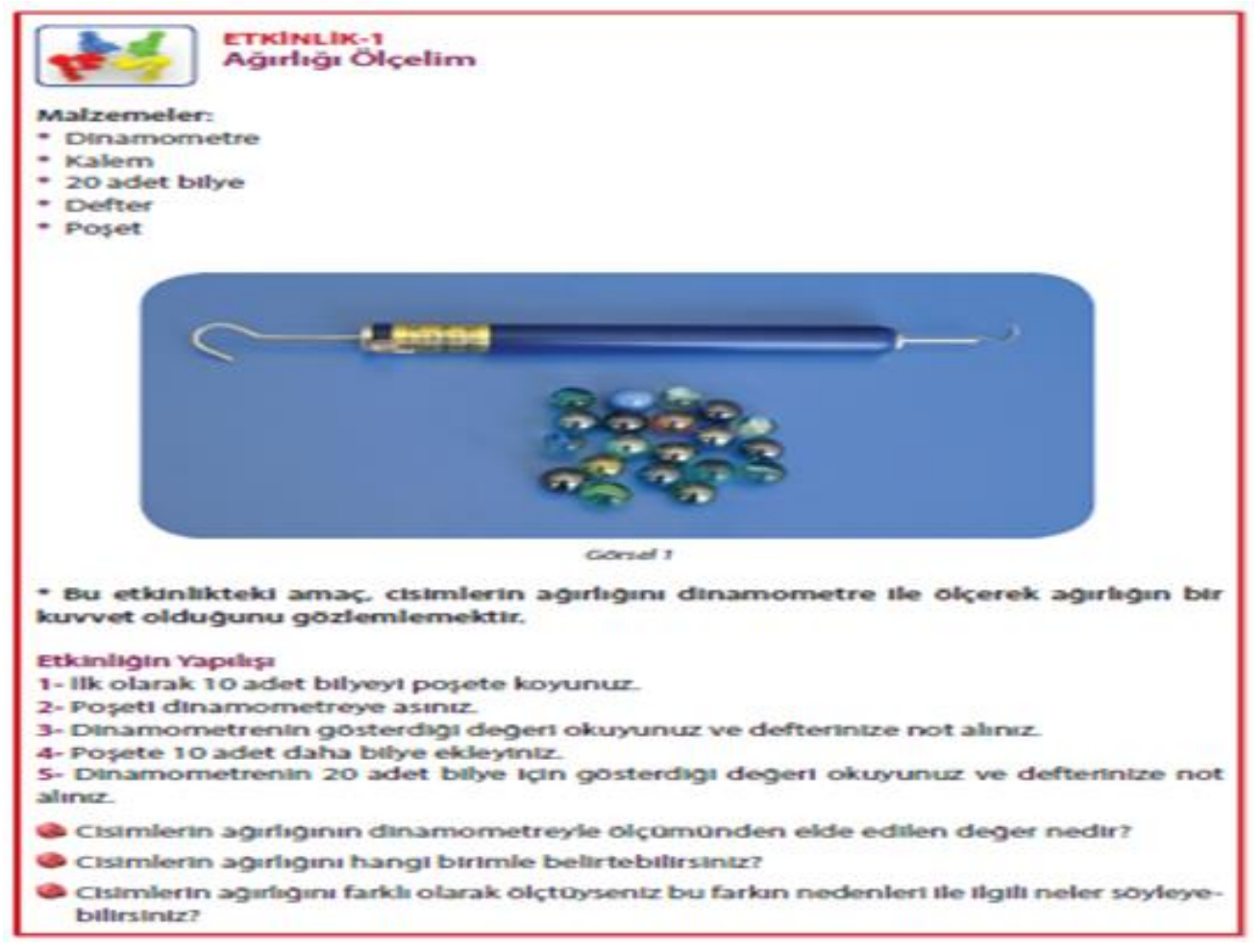

Şekil 3. "Bilim İnsanları, Aynı Deneysel Veriyi Farklı Biçimlerde Yorumlayabilir" Temasına Örnek (1.K, s.82)

1K kitabında Kuvvet ve Enerji ünitesinde sayfa 82'deki etkinlikte öğrencilerin yapılacak olan deneyde sonuçları farklı bulmalarının sebeplerine vurgu yapılması sağlanmıştır. 91. ve 98. sayfalarında da 7. temaya vurgu yapılmıştır. Öğrenciler aynı deneyleri yaparken ölçme aracından, gözlemciden veya ortamdan kaynaklı hataların olabileceği, verilerin yorumunda öznel olunacağına yönelik çıkarımlarda bulunabilir. Bu etkinlikte benzer durumun bilim insanları için de geçerli olabileceğine dolaylı olarak değinilebilir.

Birinci kitapta Kuvvet ve Enerji ünitesinde 9. tema olan "bilimsel fikirler, oluşturulduğu sosyal ve tarihsel ortamdan etkilenir" temasına kitabın 99. ve 100. sayfalarında vurgu yapılmıştır. Bu sayfalardan 100. sayfaya yönelik metin Şekil 4'te verilmiştir.

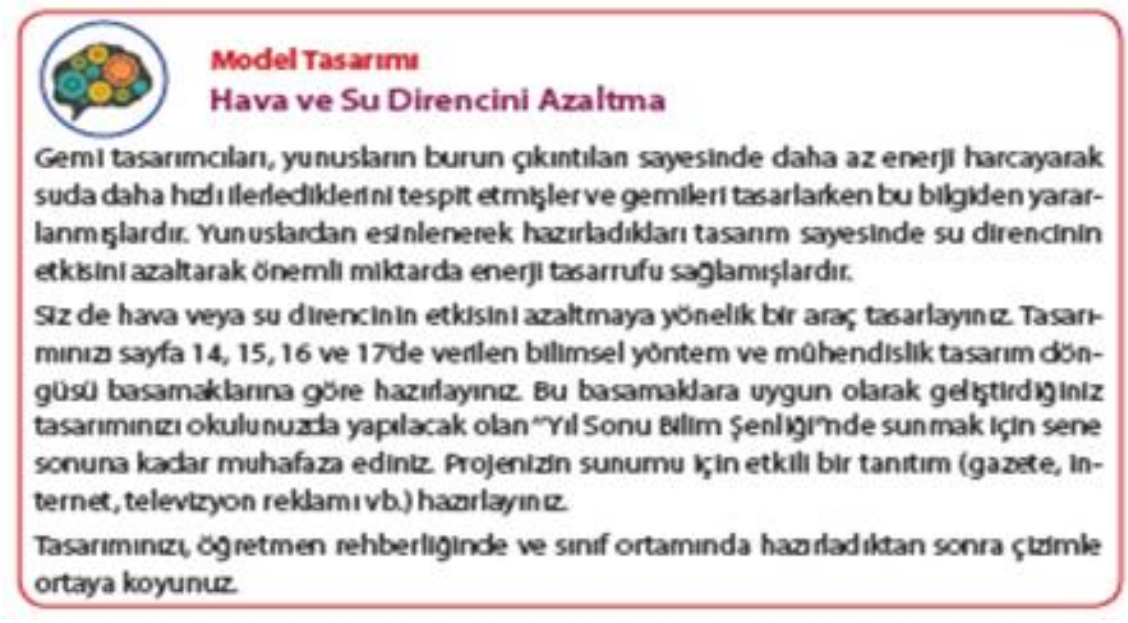

Şekil 4. "Bilimsel Fikirler, Oluşturulduğu Sosyal ve Tarihsel Ortamdan Etkilenir" Temasına Örnek (1.K, s.100) 
Şekil 4, 100. sayfada verilen etkinlikte yunusların hareketinden esinlenerek gemilerin tasarlandığı, sayfa 99'da kuş gagasından esinlenerek Japonya'da hızlı trenlerin tasarımının yapıldığı bilgisi verilmektedir. Bu etkinlikler bilimsel fikirlerin içinde bulunduğu ortamdan etkilendiğine birer örnektir. Model tasarımı başlığında verilen bu bilgilerde öğrenciler bilimsel yöntem ve mühendislik tasarım döngüsü basamaklarına yönlendirilmiştir. Esasında "evrensel ve aşama aşama ilerleyen bir bilimsel yöntem yoktur" bilimin doğas 13 . temasına uygun olmayan bir yönlendirme mevcuttur. Öğrencilerin yapacakları modelde tek bir adımı takip etmeleri ilerde bilimin doğasına yönelik tanılanan bir mite neden olabilir.

\section{Kitapta Bilimin Doğası Temalarının Temsili}

2. kitaba ait bulgular Tablo 1'de incelendiğinde 4. tema olan "gözlemler teori yüklüdür" temasında en fazla frekansın olduğu görülür ki bunların tamamı kitapta dolaylı olarak belirtilmektedir. Öğrencinin gözlemleri üzerinden yorumlar yapması yani çıkarımda bulunması istenmektedir. Sayfa 71'deki örnek Şekil 5'te verilmiştir.

\section{Ağırlık Nedir?}

Yağmur damlalarının, havaya attığınız topun ve ağaçtaki meyvelerin bir süre sonra yere düştüğünü gözlemlemișsinizdir. Bunlar gibi dünya üzerindeki bütün cisimler belli bir yükseklikten bırakıldıklarında ya da serbest kaldıklarında yere doğru düşmektedir. Acaba tüm bu varlıkların yere doğru hareketini sağlayan etki nedir?
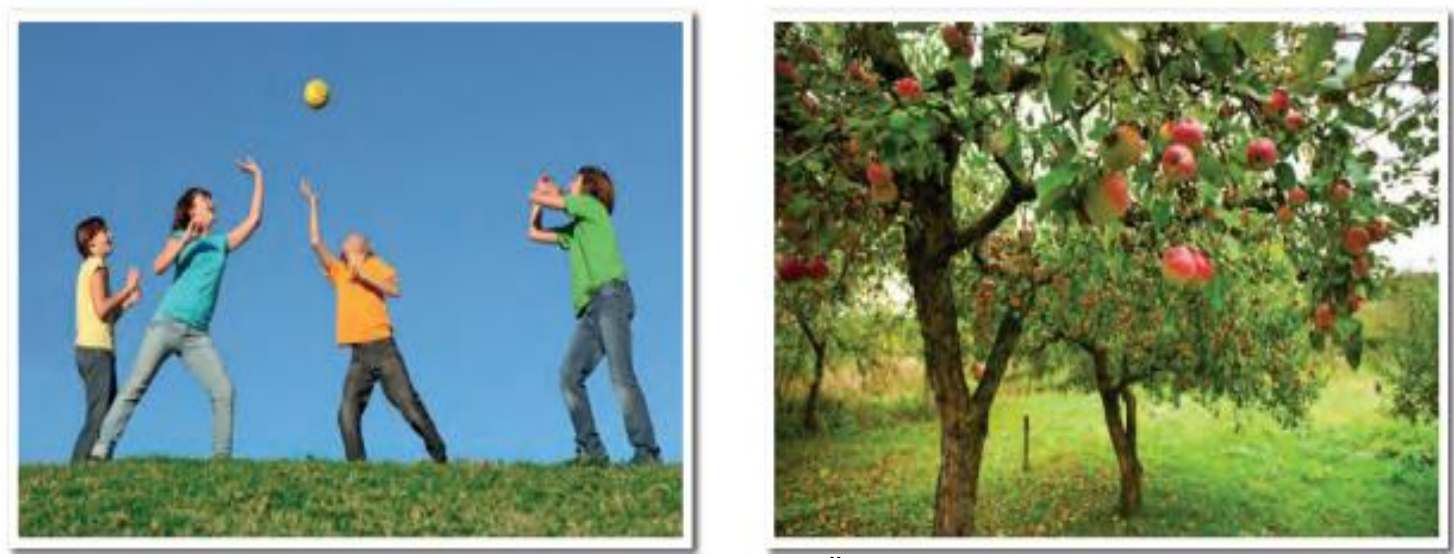

Şekil 5. “Gözlemler Teori Yüklüdür” Temasına Örnek (2.K, s.71)

Şekil 5, bölüm başında verilen bu sorularla öğrencilerin sorgulaması, gözlemleriyle ilgili akı1 yürütmede ve çıkarımda bulunması istenmektedir. Kitabın geneli için sayfa 76, 80, 81, 83, 84, 90 da bu temaya ait örnekler bulunmaktadır. Bireysel deneyimler ve dünyaya bakış açıları gözlemlerin yorumunu etkiler. Bilim insanları da gözlem yaparken zihinsel teorilerine göre davranır. Kitapta etkinliklerde doğrudan bilimin doğası teması verilmemektedir; öğrencilerin dolaylı çıkarımı hedeflendiği için Tablo 1'de D (değinilmiş) olarak kodlanmıştır.

5. tema olan "bilimsel bilgi tamamen olmasa da çoğunlukla gözleme, deneysel kanıta, rasyonel argümanlara, yaratıcılığa ve şüpheciliğe dayalıdır" temasına 8 defa değinilmiştir. Sayfa $72,76,78,81,83,88,90,92$ verilen etkinliklerde öğrencinin gözlem yapması deneysel kanıta dayalı sonuç çıkarması istenmektedir. Yine doğrudan bir açıklama ile değil öğrencinin bilimin doğasına ait dolaylı çıkarımda bulunması söz konusudur. Bu çıkarıma yönelik etkinlik Şekil 6' da verilmiştir. 


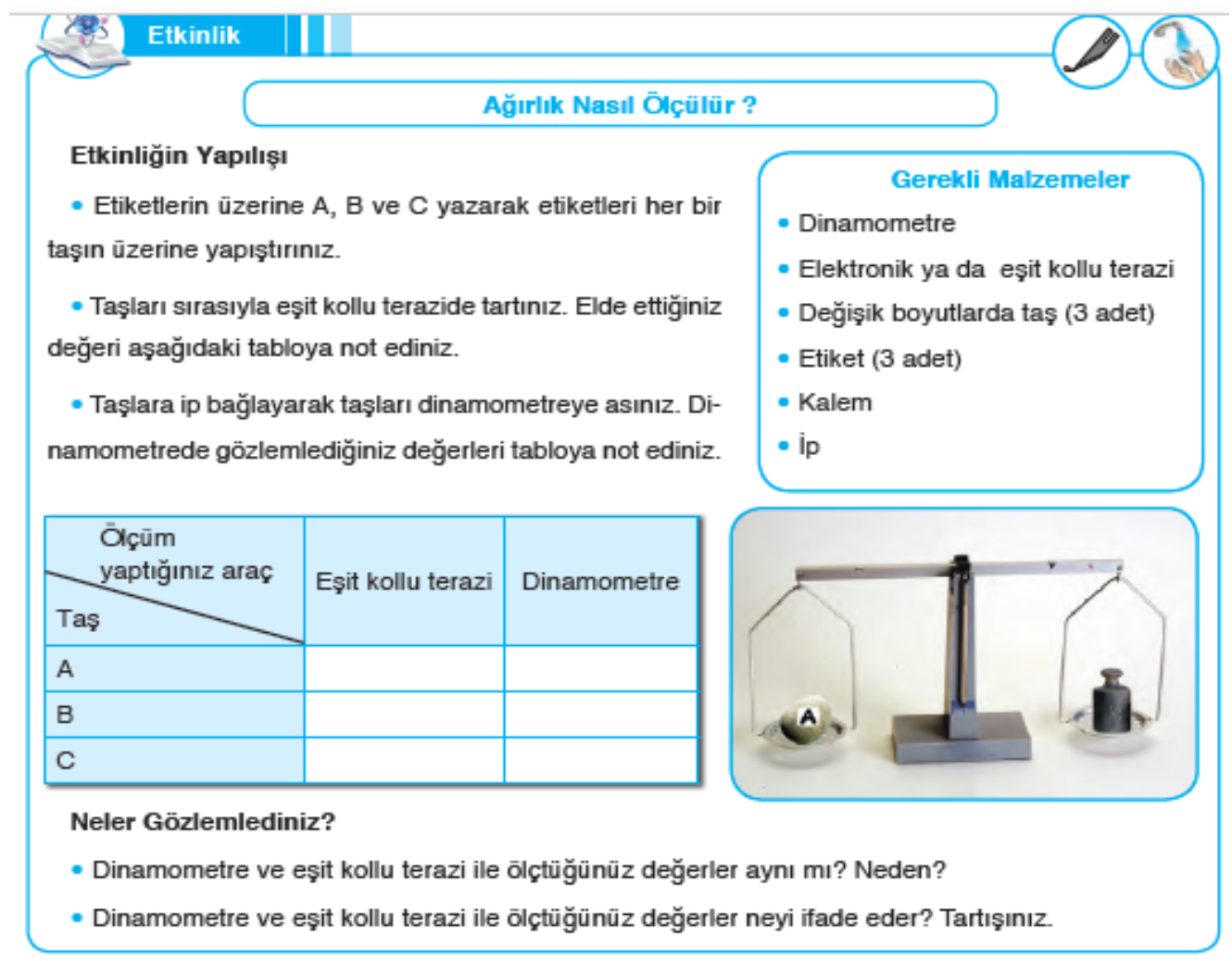

Şekil 6. "Bilimsel Bilgi Tamamen Olmasa Da Çoğunlukla Gözleme, Deneysel Kanıta, Rasyonel Argümanlara, Yaratıcılığa ve Şüpheciliğe Dayalıdır” Temasına Örnek (2.K, s.72)

Şekil 6, etkinliğin altında ağırlık ve kütle kavramı açıklandıktan sonra "... Etkinlikte; eşit kollu terazi ile taşların kütlesini, dinamometre ile ağırlığını belirlediniz. Kütlesi büyük olan taşın ağırlığının da büyük olduğunu fark ettiniz mi?" sorusu verilmiştir. Öğrencinin deneyle ilişkili akı1 yürütme yapması istenmektedir. Sayfa 81'deki etkinlikten sonra da açıklamada "... Yaptığınız etkinlikte, cismin sürati ve kütlesi arttığında yapılan işin arttı̆̆ını ve bunun sonucunda kinetik enerjisinin de değiştiğini gözlemlediniz. O hâlde bir cismin sürati veya kütlesi arttıkça kinetik enerjisinin de arttı̆̆ sonucuna ulaşabilirsiniz." bilginin deneysel kanıt ve akıl yürütmeye dayalı olduğu sonucu çıkarılabilir. Sayfa 88'deki etkinlikte lunaparktaki hız treninde enerji dönüşümü anlatılmıştır. Burada da bilimsel bilginin deney ve gözleme dayandığı ve akıl yürütme sürecini içerdiği vurgulanmaktadır.

9. tema olan "bilimsel fikirler, oluşturulduğu sosyal ve tarihsel ortamdan etkilenir" temas1, sayfa 91, 94 ve 95'te verilmektedir. Bu temaya yönelik örnek Şekil 7'de verilmiştir. 
Kuşların vũcut yapılan ve uçmalarından esinlenilerek uçaklar ûretilmiştir. Uçaklar hava direncini en aza indirecek șekilde tasarlanır. Bu araçların uçlanı sivridir. Dış yũzeylerinde ise pürũzsüz ve kaygan malzemeler kullanılır. Uçakların inişi sırasında hava direncini artırmak için kanatların üzerindeki yapılar açılır. Bỏylece uçak yavașlar ve güvenli bir iniş gerçekleşir. Otomobil, tren gibi araçlar da hava direncini en aza indirecek şekilde tasarlanır. Böylece havanın üstten ve yan taraflardan aracın alt kısımlanına gőre daha hızlı dolanması sağlanarak hava direnci azaltılır.
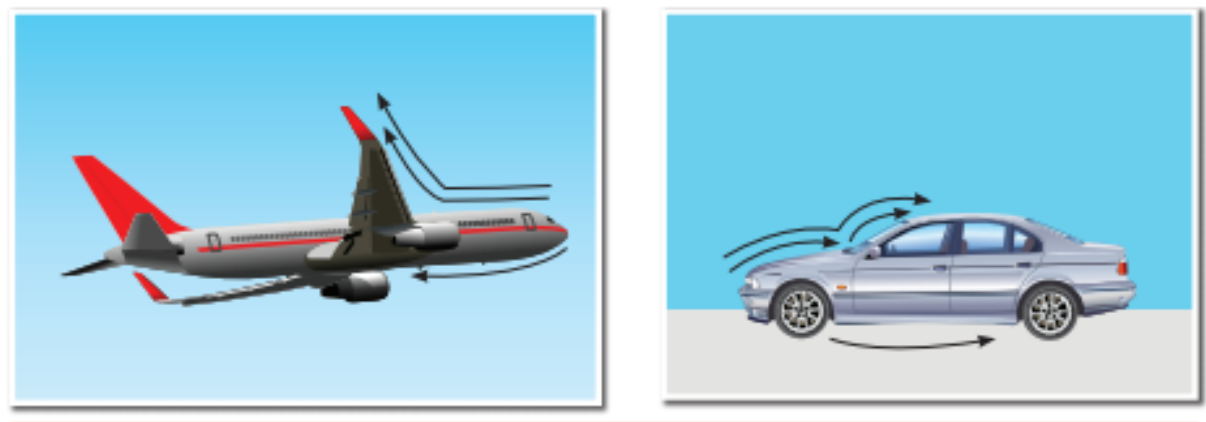

Şekil 7. "Bilimsel Fikirler, Oluşturulduğu Sosyal Ve Tarihsel Ortamdan Etkilenir" Temasina Örnek (2. K, s. 94)

Şekil 7, kitapta hava ve su direncini azaltmaya yönelik önlemlerin doğadaki örneklerden hareketle geliştirildiğine değinilmiștir. Sayfa 94'te "Suda yaşayan canlıların vücut yapıları su direncinden en az etkilenecek şekildedir. Balıkların vücutlarının kaygan olması ve üzerlerindeki pullar su dirençlerini azaltarak hareketlerini kolaylaştırır" sayfa 95'te "Suda ulaşım veya taşımacılık amacıyla kullanılan gemi, sandal, feribot gibi araçların şekillerine hiç dikkat ettiniz mi? Bu araçlar su direncinden daha az etkilenecek şekilde tasarlanmuştır. Örneğin gemilerin ön kısımları, su ile temas yüzeyini azaltarak su direncini azaltmak için " $V$ ” şeklinde yapılır. Ayrıca denizaltıların ön kısımları su direncini azaltacak şekilde tasarlanmıştır. Böylece bu araçlar suda hızlı hareket edebilir." bilgisi ile su direncini azaltmaya yönelik önlemler olarak verilmiştir.

İncelenen ilk kitaptan (MEB yayını) farklı olarak özel yayınevine ait olan 2. kitapta 8. tema olan "bilimsel teorilerin gelişimi bazen çelişen temellere dayalıdır" teması bulunmuştur. Bu bilgi kutucuğuna yönelik örnek Şekil 8'de sunulmuştur.

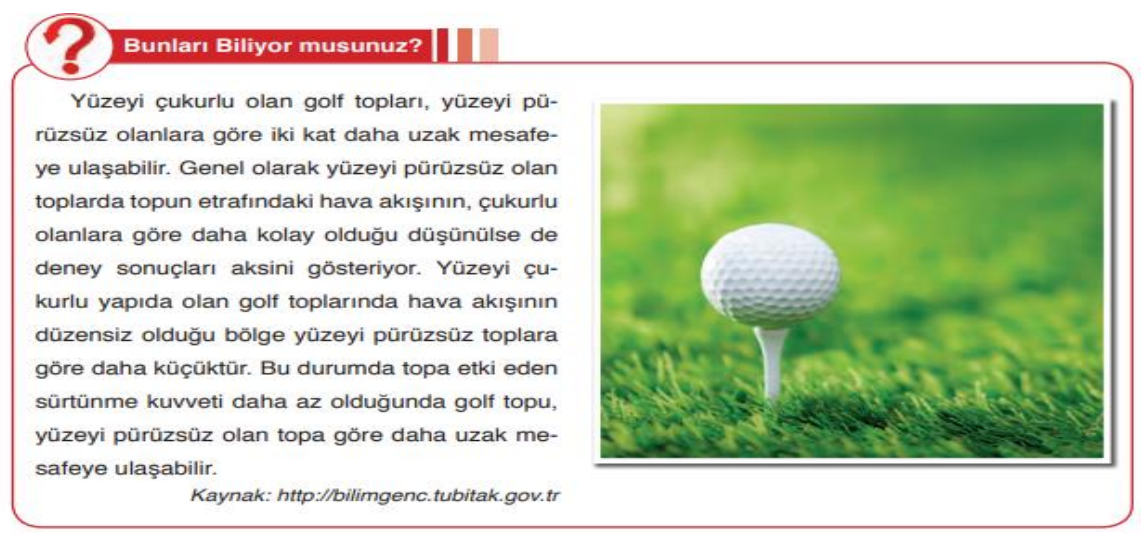

Şekil 8. "Bilimsel Teorilerin Gelişimi Bazen Çelişen Temellere Dayalıdır" Temasına Örnek (2.K, S. 95)

Şekil 8, Sayfa 95'teki bilgi kutucuğunda golf topunun çukurlu yüzeyinin hareketi nasıl etkilediği açıklanmıştır. Sürtünme kuvvetinin hareketi engelleyici bir etki olduğu, dolayısıyla golf 
topunun havada hareketi sırasında maruz kaldığı hava direncinin temas yüzeyinin artmasıyla yavaşlayacağı şeklideki teoriye alternatif bir açıklama üretilmiştir.

\section{TARTIŞMA , SONUÇ VE ÖNERILLER}

Ortaokul 7. sinıflarda okutulmakta olan, EBA'da belirtilen 2 fen bilimleri ders kitabında Kuvvet ve Enerji ünitesi bilimin doğası temalarını içermelerine göre incelenmiştir. Yapılan analize göre en fazla temsil edilen temaların dördüncü tema olan "gözlemler teori yüklüdür" ve beşinci tema olan "bilimsel bilgi tamamen olmasa da çoğunlukla gözleme, deneysel kanıta, rasyonel argümanlara, yaratıcılığa ve şüpheciliğe dayalıdır" temalarından toplamda dört kez değinildiği bulunmuştur. 7. tema olan "bilim insanları, aynı deneysel veriyi farklı biçimlerde yorumlayabilir" ve 8. tema olan "bilimsel teorilerin gelişimi bazen çelişen temellere dayalıdır" toplamda birer kez değinilmiştir. 9. tema olan "bilimsel fikirler, oluşturulduğu sosyal ve tarihsel ortamdan etkilenir" teması toplamda iki kez değinilmiştir. 1. tema olan "bilimsel teorilerin geçici/kesin olmayan doğası vardır" teması, 2. tema olan "bilimde yasa ve teorilerin farklı rolleri vardır (Teoriler ilave kanıtlarla birlikte yasalara dönüşmez.)" teması, 3. tema olan "evrensel ve aşama aşama ilerleyen bir bilimsel yöntem yoktur" teması ve 6. tema olan "bilimsel ilerleme, rakip teoriler arasındaki rekabet ile nitelendirilir" temalarından hiç bahsedilmemiştir.

İncelenen iki kitapta da ilgili ünitede etkinlikler yoluyla bilimin doğasının dolaylı öğretimi sağlandığı söylenebilir. Akerson, Abd-El-Khalick ve Lederman, (2000); Schwartz ve Lederman, (2002), öğrencilere bilimin doğası öğretiminde doğrudan yaklaşımın diğer yaklaşımlara göre daha etkili olduğu bildirmişlerdir. Bilimin doğası kazanımlarının etkinlikler içinde belirtilmesi öğrencilerin bilimin doğası hakkında doğru ve ortak sonuçlar çıkartabilmesi için önemlidir. Öğretmenlerin temel kaynak olarak kullandığı fen ders kitaplarındaki bilimin doğasına ilişkin yanlış temsillerin, öğretmen ve öğrencilerde bilimin doğasına dair öğretim sürecini olumsuz etkileyeceğinden (Abd-El-Khalick ve diğerleri, 2008) ders kitaplarının bilimin doğası kazanımlarını açıklayıcı bir şekilde yazılması ve bu kazanımlara yönelik doğrudan öğretimi sağlayacak etkinlikler içermesi gerekir. Konunun doğasına göre bilim tarihinden örnekler sunup tarihsel yaklaşımdan yararlanılarak bilimin doğası temaları verilebilir. Chua, Tan ve Ramnarain (2019), inceledikleri biyoloji kitaplarında bilimin doğasıyla ilgili fark ettikleri eksiklikleri gidermek adına içerik dışı bölümlerin dahil edilmesini; bilimin doğası yönlerini doğrudan, tutarlı ve açık bir şekilde ele almak için uygun platformlar olarak önermektedir.

Koçyiğit ve Pektaş (2017) araştırmalarında, ortaokul fen bilimleri kitaplarındaki okuma parçalarında bilim tarihinin kullanımı bakımından kavramsal, prosedürel ve bağlamsal anlayışın yer aldığı ama bu durumun yeterli düzeyde olmadığını tespit etmişlerdir. Abd-El-Khalick, Waters ve Le (2008), ondört lise kimya ders kitabında bilimin doğasının temsil edilmesini ve son kırk yıl içerisinde temsil etme durumunun ne aşamada olduğunu belirlenmesi için inceleme yapmışlardır. "Deneysellik, değişebilirlik, dolaylı deliller, yaratıcılık, bilimde teorik kabuller, bilimsel teori ve yasaların doğası, bilim-toplum ilişkisi ile bilimsel yöntem" temalarının ders kitaplarında yeterli düzeyde yer almadıkları ve son 40 yılda temsil etme durumlarının daha da kötüleştiğini belirtmişlerdir. Duruk ve Akgün (2020), 6-7-8. fen bilimleri ders kitaplarının "teori kökenli olma, bilimsel teorilerin doğası, bilimin sosyal yönü, bilim ve teknoloji farklılığı, bilimsel modeller, bilim-sözdebilim ayrımı" temalarına değinmediğini bilimin doğasını ele alış bakımından yetersiz olduğunu belirtmiştir. İrez (2009) ortaöğretim biyoloji ders kitaplarının bilimin doğasının bazı yönlerini ihmal ettiğini ve bilimin doğasını yetersiz temsil ettiğini bildirmektedir. Şahin (2016) kimya ders kitaplarının bilimin doğası kazanımları bakımından yetersiz ve dengesiz bir dağılım gösterdiğini ifade etmiştir. Abd-El-Khalick ve diğerleri (2017), ABD'deki lise biyoloji ders kitaplarında bilimin doğası temalarını kapsamlı bir şekilde analiz ettiğinde ders kitaplarının bilimin doğasına çok düşük bir sayfa oranı ayırdığını bulmuşlardır. 
Ders kitapları öğretim programı esas alınarak hazırlanan öğretim materyalleridir. Öğretim programlarında bilimin doğası kazanımlarının daha açık ve net değinilmesi gerekir. Özden ve Cavlazoğlu (2015), 2005 ve 2013 öğretim programlarını ilkokul ve ortaokul tüm sınıf düzeylerinde inceledikleri nitel çalışmada bilim doğasının sınırlı temsil edildiği temaların çoğundan bahsedilmediğini ifade etmişlerdir.

Fen bilimleri dersinde, ders kitabı kullanımı öğrenci eğitiminde önemli yer tutmaktadır (Chiappetta, Sethna ve Fillman, 1993). 7. sinıf Kuvvet ve Hareket ünitesinin incelendiği bu araştırmada bilimin doğası temalarından bilimsel teorilerin yapıs1; yasa ve teori farkı; bilimsel yöntem; bilimsel ilerlemede rakip teorilerin rolü temalarına hiç değinilmediği tespit edilmiştir. Kitaplarda verilen örneklerin daha çok dolaylı olarak bilimin doğasını öğretiminde kullanıldığı söylenebilir.

Çalışmanın sonucuna uygun olarak verilen öneriler şunlardır:

- Öğrencilere bilimsel okuryazar olarak yetiştirilmesinde önemli bir bileşen olan bilimin doğası öğretiminin sağlanabilmesi için ders kitaplarının bilimin doğası temalarının öğretimine destek olacak etkinlikler bakımından zenginleştirilmesi gerekir.

- Öğretim programındaki kazanımlar ders kitaplarında ele alınırken bilimin doğası temalarının tümü göz önüne alınmalıdır.

- Kitaplardaki etkinliklerin açıklamaları öğrenciyi bilimin doğası temalarına net bir şekilde yönlendirilebilir; veya sayfada içerik dışı açıklamalarla bilimin doğası temaları vurgulanabilir.

- $\mathrm{Bu}$ araştırmanın kapsamı bir ünite ile sınırlandırılmışıtır. Tüm sınıf düzeylerindeki fen kitapları bilimin doğası temaları bakımından incelenebilir.

- Fen konularına yönelik bilimin doğası etkinlik materyalleri ve uygulama örnekleri hazırlanarak yardımcı kaynak kullanımına sunulabilir.

- Literatürdeki farklı sınıflandırmalar da dikkate alınarak kitapların incelenmesi ve öğretim programlarındaki kazanımlara bilimin doğasına yönelik kazanımlar eklenmesi önerilmektedir.

\section{KAYNAKÇA}

AAAS. (1993). Science for all Americans: Project 2061. New York: Oxford University Press.

Abd-El-Khalick, F., \& Akerson, V. L. (2004). Learning about nature of science as conceptual change: Factors that mediate the development of preservice elementary teachers" views of nature of science. Science Education, 88, 785-810.

Abd-El-Khalick, F., Bell, R. L., \& Lederman, N. G. (1998). The nature of science and instructional practice: Making the unnatural natural. Science Education, 82(4), 417-436.

Abd-El-Khalick, F., Waters, M., \& Lee, P. (2008). Representations of nature of science in high school chemistry textbooks over the past four decades. Journal of Researching In Science Teaching, 45(7), 835-855.

Abd-El-Khalick, F., Myers, J. Y., Summers, R., Brunner, J., Waight, N., Wahbeh, N., et al. (2017). A longitudinal analysis of the extent and manner of representations of nature of science in us high school biology and physics textbooks. Journal of Research in Science Teaching, 54(1), 82-120

Abraham, M. R., Grzybowski, E. B., Renner, J. W., \& Marek, E. A. (1992). Understanding and misunderstandings of eighth graders of five chemistry concepts found in textbooks. Journal of Research in Science Teaching, 29, 105-120. 
Akdemir, E. ve Çetin Aksoy, D. (2019-1.K). Ortaokul ve imam hatip ortaokulu 7. sinıf fen bilimleri ders kitabı. Devlet Kitapları (1. Baskı). Milli Eğitim Bakanlığı Yayınları.

Akerson, V. L., Abd-El-Khalick, F., \& Lederman, N. G. (2000). Influence of a reflective explicit activity-based approach on elementary teachers' conceptions of nature of science. Journal of Research In Science Teaching, 37(4), 295-317.

Akerson, V. L., Buzzelli, C. A., \& Donnelly, L. A. (2008). Early childhood teachers' views of nature of science: The influence of intellectual levels, cultural values, and explicit reflective teaching. Journal of Research in Science Teaching, 45(6), 748-770.

Aslan, O., Yalçın, N. ve Taşar, M. F. (2009). Fen ve teknoloji öğretmenlerinin bilimin doğası hakkındaki görüsleri, Ahi Evran Üniversitesi Eŭitim Fakültesi Dergisi, 10(3), 1-8.

Aydede, M. N. (2006). İlköğretim altıncı sınıf fen bilgisi dersinde aktif ögrrenme yaklaşımını kullanmanın akademik başarl, tutum ve kalıcılık üzerine etkisi. (Yüksek Lisans Tezi). Çukurova Üniversitesi Sosyal Bilimler Enstitüsü. Adana.

Aydın, S. ve Tortumlu, S. (2015). The analysis of the changes in integration of nature of science into Turkish high school chemistry textbooks: Is there any development? Chemistry Education Research and Practice, 16, 786-796.

Bell, R. L., Abd-El-Khalick, F., Lederman, N. G., McComas, W. F., \& Matthews, M. R. (2001). The nature of science and science education: A bibliography. Science and Education, 10, 187-204.

Bianchini, J. A., \& Colburn, A. (2000). Teaching the nature of science through inquiry to prospective elementary teachers: A tale of two researchers. Journal of Research in Science Teaching, 37(2), 177-209.

Cansız Aktaş, M. (2019). Nitel veri toplama teknikleri. H. Özmen \& O. Karamustafaoğlu (Ed.), Eğitimde araştırma yöntemleri (s. 114-135) içinde. Ankara: Pegem Akademi Yayıncılık.

Chiang-Soong, B., \& Yager, R. E. (1993). Readability levels of the science textbooks most used in secondary schools. School Science and Mathematics, 93(1), 24-27.

Chiappetta, E. L., Sethna, G. H., \& Fillman, D. A. (1993). Do middle school life science textbooks provide a balance of scientific literacy themes? Journal of Research in Science Teaching, 30(7), 787-797.

Chiappetta, E. L., Ganesh, T. G., Lee, Y. H., \& Phillips, M. C. (2006). Examination of science textbook analysis research conducted on textbooks published over the past 100 years in the United States. Paper presented at the Annual Meeting of the National Association for Research in Science Teaching, San Francisco, CA.

Chiappetta, L. E., \& Fillman, D. A. (2007). Analysis of five high school biology textbooks used in the united states for inclusion of the nature of science. International Journal of Science Education, 29(15), 1847-1868.

Chua, J. X., Tan, A. L., \& Ramnarain, U. (2019). Representation of NOS aspects across chapters in Singapore grade 9 and 10 biology textbooks: Insights for improving NOS representation. Research in Science \& Technological Education, 37(3), 259-278.

Çepni, S. (2014). Araştırma ve proje çalışmalarına giriş. Trabzon.

Doğan Bora, N. (2005). Türkiye genelinde ortaöğretim fen branşl ögretmen ve öğrencilerinin bilimin doğası üzerine görüşlerinin araştırılması. (Yayınlanmamış Doktora Tezi). Gazi Üniversitesi Eğitim Bilimleri Enstitüsü. Ankara. 
Doğan, N., Han Tosunoglu, Ç., Özer, F. ve Akkan, B. (2020). Ortaokul öğrencilerinin bilimsel sorgulama görüssleri: Cinsiyet, sınıf düzeyi ve okul türü değişkenlerinin incelenmesi. Pamukkale Üniversitesi Eğitim Fakültesi Dergisi, 49, 162-189.

Duruk, Ü. ve Akgün, A. (2020). Bilimin doğası bileşenlerinin fen bilimleri ders kitaplarında temsil edilme durumu. Amasya Üniversitesi Eğitim Fakültesi Dergisi, 9(2), 196-229.

Harlen, W. (2001). Primary science: Taking the plunge. (2nd Ed.).Portsmouth, NH: Heinemann.

Hubisz, J. (2003). Middle-school texts don't make the grade. Physics Today, 50(5), 50-54.

Irez, S. (2009). Nature of science as depicted in Turkish biology textbooks. Science Education, 93(3), 422-447.

Koçyiğit, A. ve Pektaş, M. (2017). Ortaokul fen bilimleri ders kitaplarındaki okuma parçalarının bilim tarihi kullanımı açısından incelenmesi. Cumhuriyet International Journal of Education-CIJE, 6(1), 185-199.

Köseoğlu, F., Atasoy, B., Kavak, N., Akkuş, H., Budak, E., Tümay, H., ve diğerleri. (2003). Yapılandırıcı öğrenme ortamı için: Bir fen ders kitabı nasıl olmalı? Ankara: Asil Yayın Dağıtım.

Lederman, J. S., Lederman, N. G., Bartels, S., Jimenez, J., Akubo, M., et al. (2019). An international collaborative investigation of beginning seventh grade students' understandings of scientific inquiry: Establishing a baseline. Journal of Research in Science Teaching, 56(4), 486-515.

Lederman, N. G. (1992). Students' and teachers' conceptions of the nature of science: A review of the research. Journal of Research in Science Teaching, 29(4), 331-359.

Lederman, N. G. (2007). Nature of science: Past, present and future. In S. K. Abell \& N. G. Lederman (Ed.), Handbook of research on science education (pp. 831-879). London: Lawrence Erlbaum Associates.

McComas, W. F., \& Olson, J. K. (1998). International science education standards documents. In McComas (Ed.), The nature of science in science education: Rationales and strategies (pp. 41-52). The Netherlands: Kluwer Academic Publishers.

McComas, W. F., Clough, M. P., \& Almazroa, H. (1998). The role and character of the nature of science in science education. In W. F. McComas (Ed.), The nature of science in science education rationales and strategies (pp. 3-39). London: Kluwer Academic Publishers.

Miles, M. B. \& Huberman, A. M. (1994). Qualitative data analysis: An expanded sourcebook (2nd Edition). Calif.: SAGE Publications.

Millî Eğitim Bakanlığı [MEB]. (2005-2013-2017-2018). Ilköğretim kurumları fen bilimleri dersi ögretim programı. Ankara: Talim ve Terbiye Kurulu Başkanlığı.

Muğaloğlu, E. Z. (2006). Fen bilgisi ögretmen adaylarının bilimin doğasına ilişkin görüşlerini açıklayıcı bir model çalışması. (Yayınlanmamış Doktora Tezi). Marmara Üniversitesi Eğitim Bilimleri Enstitüsü. İstanbul.

Muşlu, G. (2008). İlköğretim 6. sınıf öğrencilerinin bilimin doğasını sorgulama düzeylerinin tespiti ve çeşitli etkinliklerle geliştirilmesi. (Yayınlanmamış Doktora Tezi). Marmara Üniversitesi Eğitim Bilimleri Enstitüsü. İstanbul.

National Research Council [NRC]. (1996). National science education standards. Washington, DC: National Academies Press.

National Science Teachers Association [NSTA]. (2013). NSTA offers recommendations on NGSS public draft. NSTA Reports, 24(7), 8-9. 
NGSS Lead States. (2013). Next generation science standards: For states, by states. Washington, DC: The National Academy Press.

Niaz, M., \& Maza, A. (2011). Nature of science in general chemistry textbooks. Springer.

Niaz, M. (2009). Progressive transitions in chemistry teachers' understanding of nature of science based on historical controversies. Science \& Education, 18, 3-65.

Norris, S. P., \& Phillips, L. M. (2003). How literacy in its fundamental sense is central to scientific literacy. Science Education, 87(2), 224-240.

Overman, M., Vermunt, J. D., Meijer, P. C., Bulte, A. M. W., \& Brekelmans, M. (2013). Textbook questions in context-based and traditional chemistry curricula analysed from a content perspective and a learning activities perspective. International Journal of Science Education, 35(17), 2954-2978.

Oyman, N. Y. (2002). İlköğretim fen bilgisi ögretmenlerinin bilimin doğası hakkındaki anlayışlarının tespiti. (Yayınlanmamış Yüksek Lisans Tezi). Marmara Üniversitesi Eğitim Bilimleri Enstitüsü. İstanbul.

Özden, M. ve Cavlazoğlu, B. (2015). İlköğretim fen dersi öğretim programlarında bilimin doğası: 2005 ve 2013 programlarının incelenmesi. Eğitimde Nitel Araştırmalar Dergisi, 3(2), 4065.

Schwartz, R. S., \& Lederman, N. G. (2002) . "It's the nature of the beast": The influence of knowledge and intentions an learning and teaching nature of science. Journal of Research in Science Teaching, 39(3), 205-236.

Seyrek, A., Türker, S., Bozkaya, T. ve Üçüncü, Z. (2019-2.K). Ortaokul ve imam hatip ortaokulu 7. sinıffen bilimleri ders kitabı. Ankara: Tutku Yayıncilık.

Stern, L., \& Roseman, J. (2004). Can middle school science textbooks help students learn important ideas? Findings from Project 2061's curriculum evaluation study: Life science. Journal of Research in Science Teaching, 41(6), 538-568.

Şahin, Ş. ve Köseoğlu, F. (2016). Bilimin doğasına ilişkin kazanımlar açısından Türkiye'deki lise kimya ders kitapları. Cumhuriyet International Journal of Education-CIJE, 5(4), 103125.

Şahin, Ş. (2016). Lise kimya ders kitaplarının bilimin doğası kazanımları yönünden içerik analizi. (Yayınlanmamış Doktora Tezi). Gazi Üniversitesi Eğitim Bilimleri Enstitüsü. Ankara.

Taşar, M. F. (2003). Teaching history and the nature of science in science teacher education programs. Pamukkale Üniversitesi Eğitim Fakültesi Dergisi, 1(13), 30-42.

Vesterinen, V. M., Aksela, M., \& Lavonen, J. (2013). Quantitative analysis of representations of nature of science in nordic upper secondary school textbooks using framework of analysis based on philosophy of chemistry. Science \& Education, 22, 1839-1855.

Yıldırım, A. ve Şimşek, H. (2013). Sosyal bilimlerde nitel araştırma yöntemleri (9. Baskı). Ankara: Seçkin Yayıncılık.

Yörükoğulları, E. (2013). Tarih öncesi çağlarda bilim ve teknoloji. E.Yörükoğulları \& E.İhsanoğlu (Ed), Bilim ve teknoloji tarihi (s. 2-27) içinde. Eskişehir: Anadolu Üniversitesi Yayını. 


\section{EXTENDED ABSTRACT}

\section{Introduction}

The ability of societies to adapt to the information age and to produce effective solutions to various problems brought about by scientific and technological developments is only possible with an effective education and training process and individuals with science literacy who will be trained at the end of this proces. An important component of scientific literacy is the nature of science, and it is stated that scientific literacy will be gained through a science education based on the nature of science. The special purposes of the 2018 science curriculum also emphasize the nature of science. Although many definitions are made about the nature of science, the characteristics of the nature of science are changeable structure of scientific knowledge, experimentation, scientific method, creativity, place of imagination and subjectivity, difference of theory and law, difference of observation and inference, social and the themes of the influence of the cultural structure are emphasized. Research in the literature indicates the inadequacy of the understanding of teachers, teacher candidates and students at different levels towards the nature of science. Two of the most important reasons for the emergence of this condition can be mentioned. The first concerns the process of training teachers. The second relates to the way subjects are integrated into the curriculum and textbooks. Textbooks are important for science education and are frequently used teaching materials. The level of representation of the nature of science in textbooks in different countries has been a very popular topic in recent years. Vesterinen, Aksela and Lavonen (2013) stated that little emphasis was placed on science and the transience dimension of the nature of science as a way to think about it as a whole in the Swedish and Finnish chemistry books, and proposed to improve the nature of science in textbooks through arrangements in curriculums. In this context, it was deemed necessary to examine the textbooks prepared according to the revised Science curriculum. The aim of this research is to examine the Force and Energy unit selected from the secondary school science textbook in terms of the themes of the nature of science.

\section{Method}

In this study, document analysis method was used from analytical research methods. The sample of the study was accepted as a textbook for 5 years with the decision of the Ministry of National Education, secondary school 7th grade Science Textbook, MEB Publications (1st Book) and a private publisher (2nd Book) are included. In the study data was collected with rubric prepared taking into account the themes of the nature of science given by Niaz and Maza (2011). In rubric, nine themes have been identified for the representation of the nature of science. Descriptive content analysis pattern was used. In the study of Niaz and Maza (2011), three evaluation levels were applied. The first level is satisfactory; second, the mentioned level; lastly it is the level that has not been mentioned. To ensure the reliability of scoring, two independent researchers scored separately. The consistency ratio of the two points was found to be 0.87 .

\section{Findings and Discussion}

According to the fact that they include the nature of science themes in the Force and Energy unit of MEB publication 1.B. and private publisher 2.B., T4 "Observations are loaded with theory." ( $\mathrm{f}=9-11)$ and T5 "Scientific knowledge is mostly, if not completely, based on observation, empirical evidence, rational arguments, creativity and skepticism." ( $f=9-8)$ is seen to be in the themes. No indirect or direct representations were found in either book for the first 3 themes. The 
Force and Energy unit contains 8 acquisitions. Taking these acquisitions into account, it was determined that the most T4 and T5 themes were mentioned in the examination of the themes of the nature of the determined science. In the activities and explanations given in both books, it is more mentioned that "scientific knowledge is based on experimentation, observation, reasoning", and that "observations are loaded with theory". It has been observed that the examples in the pages of the book are examined and the nature of science is addressed through indirect teaching. It has been found that scientific theories and laws are different, that there is no single scientific method, "the temporal/imprecise nature of scientific theories", themes related to the competition between competing theories in scientific progress are not mentioned in the books. In both books examined, it can be said that indirect teaching of the nature of science is provided through activities in the relevant unit. Akerson, Abd-El-Khalick and Lederman, (2000); Schwartz and Lederman, (2002), it is noted that the direct approach is more effective in giving students sufficient concepts about the nature of science than other approaches. Duruk and Akgün (2020) stated that the 6th-7th-8th science textbooks do not address the themes of theory origin, the nature of scientific theories, the social aspect of science, the difference in science and technology, scientific models, science- pseudoscience separation, but are inadequate in terms of addressing the nature of science. Şahin (2016) stated that chemistry textbooks show an inadequate and unbalanced distribution in terms of the inherent gains of science.

\section{Result}

In the 7th grade books examined, the Force and Movement unit was found inadequate in terms of teaching the nature of science. It is important to teach students the nature of science in order to be trained as scientific literate. Therefore, textbooks, which are the basic teaching material of teachers, should directly include the themes of the nature of science. The explanations in the examples given should clearly direct the student to the themes of the nature of science. The nature of science should not be ignored when organizing acquisitions in the curriculum. The scope of this research is limited to one unit. It is recommended to examine all units in terms of the themes of the nature of science, to examine books taking into account different classifications in the literature, and to add gains to the nature of science to the gains in teaching programs. 